\title{
Microbiological contamination in a university veterinary hospital
}

\author{
Christian Carpeggiani Giotto ${ }^{1}$ (i) Naiara Vitoria Ferreira Cortes Koprovski $^{1}$ (i) \\ Thaís Teixeira de Souza ${ }^{1}$ (D) Rosângela Abreu Monteiro de Barros ${ }^{2}$ Karina Ramirez Starikoff ${ }^{1^{*}}$ (10)
}

${ }^{1}$ Curso de Medicina Veterinária, Universidade Federal da Fronteira Sul (UFFS), 85770-000, Realeza, PR, Brasil.

${ }^{2}$ Departamento de Parasitologia, Microbiologia e Imunologia do Instituto de Ciências Biológicas da Universidade Federal de Juiz de Fora (UFJF), Juiz de Fora, MG, Brasil. E-mail: karina.starikoff@uffs.edu.br. "Corresponding author.

ABSTRACT: This study aimed to evaluate the microbiological contamination of the different sectors of a university veterinary hospital, the efficiency of the sanitation procedures performed, and the resistance to antimicrobials and disinfectants. Fourteen environmental samples and seven swab samples were collected from procedure tables of the different sectors. During analysis, the following microorganisms were found: bacterial species Rothia spp., coagulase-negative Staphylococcus spp., Staphylococcus aureus, and Enterococcus spp. and zygomycete fungi (could not be classified in genus due to the absence of reproductive structures) and other fungal species Cladosporium spp., Epicoccum spp., Drechslera spp., Scopulariopsis spp., and Penicillium spp. The bacterial species were submitted to a sensitivity assessment of the antimicrobials used in routine prescription. Rothia spp. and $S$. aureus were resistant only to erythromycin (15 $\mu$ g), coagulase-negative Staphylococcus spp. were resistant to erythromycin (15 $\mu \mathrm{g}$ ) and sulfazotrim (25 $\mu \mathrm{g})$, and Enterococcus spp. were resistant to ampicillin (10 $\mu \mathrm{g})$. For the effectiveness test of disinfectants, the products used to sanitize hospital surfaces were tested. All microorganisms in this study were resistant to $1 \%$ sodium hypochlorite solution. Rothia spp. and Enterococcus spp. were resistant to 70\% ethyl alcohol. The best results were found using pure sodium hypochlorite and benzalkonium chloride, pure and diluted to $20 \%$, which showed a bactericidal effect against all tested microorganisms. These data are relevant for knowledge of the hospital microbiota at the intersection of possible cases of hospital infections.

Key words: veterinary hospital, antimicrobial resistance, environment, disinfectants.

\section{Contaminação microbiológica em hospital veterinário universitário}

RESUMO: O objetivo desta pesquisa foi avaliar a contaminação microbiológica de diferentes setores de um hospital veterinário universitário, a eficiência dos procedimentos de higienização realizados e a resistência aos antimicrobianos das cepas encontradas. Quatorze amostras ambientais e sete amostras de swabs foram coletadas dos diferentes setores. Durante a análise foram encontradas as seguintes espécies bacterianas: Rothia spp., Staphylococcus spp. coagulase negativa, Staphylococcus aureus e Enterococcus spp.; e os seguintes fungos: zigomicetos, que não puderam ser classificados em gênero devido a ausência de estrutura reprodutiva, os demais foram Cladosporium spp., Epicoccum spp., Drechslera spp., Scopulariopsis spp. e Penicillium spp. As bactérias foram submetidas a uma avaliação de sensibilidade dos antimicrobianos utilizados prescritos na rotina. A avaliação concluiu que Rothia spp. e S. aureus foram resistentes apenas à Eritromicina (15 $\mu \mathrm{g})$, Staphylococcus coagulase negativa resistente à Eritromicina (15 $\mu \mathrm{g})$ e Sulfazotrim (25 $\mu \mathrm{g})$ e Enterococcus spp. mostrou resistência à Ampicilina $(10 \mu \mathrm{g})$. Para o teste de eficácia dos desinfetantes, foram utilizados os produtos utilizados na higienização das superficies do hospital. O teste mostrou que todos os microrganismos encontrados no estudo eram resistentes à solução de hipoclorito de sódio diluída a 1\%, Rothia spp. e Enterococcus spp. resistentes ao álcool etilico 70\%. Os melhores resultados dos testes foram encontrados com hipoclorito de sódio puro e cloreto de benzalcônio puro e diluído a 20\%, que apresentou efeito bactericida contra todos os microrganismos testados. Os dados encontrados foram relevantes para o conhecimento da microbiota hospitalar no cruzamento de possíveis casos de infecções hospitalares. Palavras-chave: hospital veterinário, resistência antimicrobiana, meio ambiente, desinfetantes.

\section{INTRODUCTION}

Hospital or nosocomial infections, currently known as healthcare-related infections, are clinical conditions resulting from patient hospitalization or the procedures performed during care, manifesting themselves during or after leaving the hospital (BRASIL, 1998).
In places where medical care is provided, whether human or veterinary, many microorganisms are spread through air, water, and surfaces. Hospital infection rates are higher in university hospitals, partly explained by the characteristics that these places offer, including the presence of more people, professionals, and students who are acquiring technical skills (ARAÚJO et al., 2018). 
Hospital infections are becoming more common in veterinary care due to the increase in the quantity and quality of intensive care performed, use of immunosuppressive drugs, increased hospitalization time, surgeries with implant placement, and exacerbated use of antimicrobials in animals (ISHII et al, 2011).

Based on this, there is the problem of the indiscriminate use of antimicrobials for treatment that, in recent years, has given rise to bacterial species resistant to different drugs or also called multidrugresistant. Antibiotic resistance is a natural process that occurs when the bacterial cell adapts to adverse situations. However, with the increased use of these drugs, the speed of the resistance process also increases; this is called selection pressure (SANTOS, 2004). The intense use of antibiotics in both human and veterinary medicine and even in food production has caused increased resistance of microorganisms worldwide.

The control of hospital infections is based on correct surface sanitation; when done properly, it guarantees an environment with reduced microbial load and appropriate for care (ANVISA, 2010). Thus, this study aimed to evaluate the microbiological contamination of the different sectors of a university veterinary hospital, the efficiency of the sanitation procedures performed, and the resistance of the isolated strains to antimicrobials and disinfectants.

\section{MATERIALS AND METHODS}

This research was conducted in June 2020, and the samples were collected after the sanitation procedures at the Veterinary University Hospital of the Federal University of Fronteira Sul, Campus Realeza, PR.

Table cleaning was performed with $2 \%$ chlorhexidine and drying with a paper towel, followed by applying $70 \%$ ethyl alcohol and drying with a paper towel. The floors were cleaned using a fabric moistened with water and then with $1 \%$ sodium hypochlorite, followed by a $30 \mathrm{~min}$ wait and removed with water.

The samples were collected in all hospital rooms where clinical or surgical care of patients took place: three ambulatories, two surgical centers (small animals and surgical technique), and the treatment sector that includes the dog kennel and cattery.

For microbiological environmental assessment, two Petri dishes were exposed on a table $\sim 1 \mathrm{~m}$ high from the floor and remained open for 15 min: one containing blood agar culture medium $\left(\mathrm{Kasvi}^{\circledR}\right)$ and the other containing Sabouraud agar (Kasvi $^{\circledR}$; SILVA et al., 2017). Next, to check the efficiency of the sanitation procedures, the surface swab technique was used, as recommended by the American Public Health Association (APHA), which recommends up to 2 colony-forming units (CFU)/ $\mathrm{cm}^{2}$ (SOUZA et al., 2016). Swabs were collected from procedure tables in ambulatories, treatment sectors, and surgical centers from a delimited area of $5 \times 5 \mathrm{~cm}$ (SILVA et al., 2017). Fourteen samples were collected from the Petri dishes, and seven samples were collected using swabs, totaling 21 samples.

The swab was initially moistened in $0.1 \%$ peptone water $\left(\mathrm{Kasvi}^{\circledR}\right)$ and transported immediately to the laboratory in a sterile tube with $10 \mathrm{~mL}$ of $0.1 \%$ peptone water, being sown on blood agar. Blood agar plates were incubated at $37{ }^{\circ} \mathrm{C}$ for 24 to $48 \mathrm{~h}$, and plates with Sabouraud agar culture medium were incubated at $25^{\circ} \mathrm{C}$ for 7 days.

Identification of bacterial species was done by macroscopic evaluation of colony characteristics, Gram staining, and biochemical tests, including catalase, coagulase $\left(\right.$ Laborclin $^{\circledR}$ ), salt tolerance with $6.5 \% \mathrm{NaCl}$ broth, esculin hydrolysis $\left(\mathrm{Kasvi}^{\circledR}\right)$, and DNase (AcuMedia ${ }^{\circledR}$ ), according to the Detection and Identification of Bacteria of Medical Importance manual of the National Health Surveillance Agency (ANVISA, 2004). In addition, bacterial colonies were inoculated in $10 \mathrm{~mL}$ BHI broth $\left(\mathrm{Kasvi}^{\circledR}\right.$ ) and incubated at $37^{\circ} \mathrm{C}$ for $24 \mathrm{~h}$, followed by a new inoculation in the mannitol agar $\left(\right.$ Mbiolog ${ }^{\circledR}$ ) and Macconkey agar $\left(\mathrm{Kasvi}^{\circledR}\right)$ culture media and incubated at $37^{\circ} \mathrm{C}$ for 24 to $48 \mathrm{~h}$.

For fungi identification, the adhesive tape technique was used, and the slides were stained with lactophenol blue solution and analyzed under an optical microscope. Identification was based on the macroscopic morphological characteristics of the colonies and microscopic characteristics of the somatic structures (hyphae: septate or coenocytic), reproductive structure (types of spores and the presence of characteristic fruiting bodies), and other structures present.

Bacterial antibiogram was performed by the disk diffusion method, with antibiotics prescribed in the hospital routine. The bacterial suspension in BHI broth was diluted with sterile distilled water to reach 0.5 using the McFarland scale and seeded on plates with Mueller Hinton agar $\left(\mathrm{Kasvi}^{\circledR}\right)$. Discs were impregnated with the following active ingredients: 10 $\mu \mathrm{g}$ ampicillin, $10 \mu \mathrm{g}$ gentamicin, $5 \mu \mathrm{g}$ ciprofloxacin, $25 \mu \mathrm{g}$ sulfazotrim, and $15 \mu \mathrm{g}$ erythromycin $\left(\right.$ Laborclin $\left.^{\circledR}\right)$. The plates were incubated at $37{ }^{\circ} \mathrm{C}$ for $24 \mathrm{~h}$. The diameter of the growth inhibition halo around the antibiotic discs was measured using a pachymeter after incubation. 
The sensitivity test to the disinfectants used in the sanitation procedures was also done: alkyl dimethyl benzyl ammonium chloride $(50 \%$ benzalkonium chloride) used pure and at $20 \%$ (according to the manufacturer's instructions), $70 \%$ ethyl alcohol, and sodium hypochlorite (active chlorine) used pure and at $1 \%$ concentration, totaling five solutions for the test.

The method consisted of applying a $20 \mu \mathrm{L}$ test solution on sterile filter paper discs and immediately placing it in Petri dishes containing Mueller Hinton agar culture medium, previously seeded with bacterial species isolated in 0.5 concentration of the McFarland scale. The dishes were then incubated at $37^{\circ} \mathrm{C}$ for 24 h (BANDEIRA et al., 2019).

Sensitivity classification was done according to the diameter of the growth inhibition halo around the disposed discs after incubation. The following parameters were used: $(-)$ nonsensitive $=$ for diameters $<8 \mathrm{~mm},(+)$ little sensitive $=$ diameters between 9 and $14 \mathrm{~mm},(++)$ sensitive $=$ diameters between 15 and $19 \mathrm{~mm}$, and $(+++)$ very sensitive $=$ diameters $>20 \mathrm{~mm}$ (NEGREIROS et al. 2016).

\section{RESULTS AND DISCUSSION}

There was microbial growth in all analyzed environments, the biggest contamination was found in the ambulatories, surgery center, dog kennel, and cattery. Four different bacterial species were found in the environments and classified as Rothia spp., coagulase-negative Staphylococcus spp., Staphylococcus aureus, and Enterococcus spp., as shown in table 1.

Zygomycetes (Phylum Zygomycota, which could not be classified in genus due to the absence of reproductive structure) and five other fungi were found and classified as Cladosporium spp., Epicoccum spp., Drechslera spp., Scopulariopsis spp., and Penicillium spp., mainly present in ambulatories and the surgery center, as shown in table 2.

Table 3 shows the results of the resistance to antimicrobials and disinfectants. All isolated bacteria showed resistance to at least one antimicrobial (highlighting $15 \mu \mathrm{g}$ erythromycin) and one disinfectant (1\% sodium hypochlorite and/or $70 \%$ ethyl alcohol).

As it is a university hospital, there is a large flow of people (mainly students who are acquiring technical knowledge) that contributes to contamination of the veterinary hospital. In addition, all components of the hospital environment (air, water, and surfaces) can serve as focal points of contact and transmission of diseases (ANDRADE et al., 2000; MORAES et al., 2013).

Even with hygiene procedures being carried out daily, this research showed the growth of three bacterial genders.

Rothia spp. are grouped in tetrad format, colonize the human respiratory tract, and are related to bronchiectasis, endocarditis, and sepsis in humans and animals (ASCHER et al., 1991; FERREIRA et al., 2015). Staphylococcus spp. are grouped in the shape of a grape cluster and asymptomatically colonize the skin, oropharynx, and gastrointestinal and urogenital tracts. However, if the host's mucous membranes are ruptured or in immunosuppression cases, these microorganisms can cause skin lesions, such as blisters and abscesses, or more serious diseases, such as pneumonia, endocarditis, urinary tract infections, and sepsis. S. aureus can remain on surfaces for

Table 1 - Bacterial contamination in the hospital rooms of a university veterinary hospital, June 2020.

\begin{tabular}{lcc}
\hline Hospital rooms & Microorganisms \\
\hline Ambulatories & Rothia spp. & CFU \\
Surgery center & Coagulase-negative Staphylococcus spp. & Rothia spp. \\
Surgical technique center & Enterococcus spp. \\
& Rothia spp. & S. aureus \\
Dog kennel & Rothia spp. \\
Cattery & Enterococcus spp. \\
\hline
\end{tabular}

$\mathrm{CFU}=$ colony forming unit. 
Table 2 - Fungal contamination in the hospital rooms of a university veterinary hospital, June 2020.

\begin{tabular}{lcc}
\hline Hospital rooms & Microorganisms \\
\hline Ambulatories & Cladosporium spp., Epicoccum spp., Penicillium spp., and zygomycetes & CFU \\
Surgery center & Cladosporium spp., Epicoccum spp., Scopulariopsis spp. and zygomycetes & 4 \\
Surgical technique center & Cladosporium spp. & 1 \\
Dog kennel & Cladosporium spp., Epicoccum spp., and Penicillium spp. \\
Cattery & Drechslera spp. & 3
\end{tabular}

$\mathrm{CFU}=$ colony forming unit

weeks or even months, increasing the contamination risk (NEELY \& MALEY, 2000; FANOURGIAKIS et al., 2003; DRESCH et al., 2018).

Enterococcus spp. are like short chains or pairs that colonize mainly the digestive tract of animals and humans, forming part of the normal intestinal flora. They can also be isolated on the skin and perianal region, via hepatobiliary, and from oropharyngeal and vaginal secretions. Enterococcus faecalis and Enterococcus faecium are the most associated with clinical manifestations, such as urinary tract infections, endocarditis, and pelvic and intra-abdominal infections (HORNER et al., 2005; TORRES et al., 2017; LIMA et al., 2020).

In this study, Staphylococcus spp. and Enterococcus spp. were similar to those performed in other veterinary establishments (ISHII et al., 2011; CAMPOS et al., 2013; SILVA et al., 2017), demonstrating that these microorganisms are common in hospital rooms.

Studies that have isolated Rothia spp. are rare. The ones available in the literature are $>15$ years old. This microorganism was isolated in patients with neoplasms and who are in neutropenic conditions. The entry point of Rothia spp. is a damaged mucous membrane with stomatitis and enterocolitis (ASCHER et al., 1991).

Cleaning and disinfection protocols for the hospital rooms were carried out daily, always after each care. Mechanical cleaning and disinfection remove dirt that predisposes to the growth of microorganisms (ANDERSEN et al., 2009). Factors that can contribute to the growth of microorganisms after hygienic procedures include not reaching the minimum contact time of the product with the surface or taking very long cleaning intervals (SFACIOTTE et al., 2014).

Resistance develops when bacteria grow and adapt in the presence of limiting factors.
Resistance is a natural and intrinsic phenomenon and can be potentiated by the inappropriate use of medications, low quality of drugs, or ineffective prevention and control strategies of infections. Based on this, antimicrobials represent $75 \%$ of all medication consumption that directly and indirectly influences the environmental microbiota (MUNDIM et al., 2003; SANTOS et al., 2010).

Resistance to antimicrobials similar to this study was found for $S$. aureus from skin infections resistant to erythromycin (BARTLETT et al., 2013), Staphylococcus spp. against sulfazotrim (CARACIOLO et al., 2012), and Enterococcus spp. against ampicillin (CDC, 2017).

According to the National Health Surveillance Agency (ANVISA, 2004), in Brazil, more than $70 \%$ of bacteria that cause nosocomial infections have been resistant to at least one antimicrobial commonly used to treat patients.

Fungi are considered opportunistic pathogens and pose a risk to immunocompromised patients with the highest incidence of diseases. The use of immunosuppressive and antimicrobial drugs should be monitored so that there is no imbalance in the patient's fungal microbiota (SILVA et al., 2014).

Among the identified fungi, Cladosporium spp. are important in veterinary medicine, as it has already been isolated in periocular lesions of felines (KOBAYASHI et al., 2011) and otomycosis cases in dogs (TORTORA et al, 2010). In human medicine, Cladosporium spp. are also considered pathogenic, associated with skin infections and sepsis cases with high mortality (TORTORA et al, 2010) isolated from a pediatric and neonatal intensive care unit (JARRAH et al., 2017). Penicillium spp. were found in a dog's fur with clinical signs of dermatophytosis (SCHROPFER et al., 2017).

In filamentous fungi, such as Penicillium spp., Fusarium spp., Cladosporium spp. and 
Table 3 - Resistance to antimicrobials and disinfectants tested from bacteria isolated from a university veterinary hospital, June 2020.

\begin{tabular}{lcc}
\hline Microorganisms & Antimicrobials & Disinfectants \\
\hline Rothia spp. & Erythromycin $(15 \mu \mathrm{g})$ & $\begin{array}{c}1 \% \text { Sodium hypochlorite } \\
70 \% \text { Ethyl alcohol }\end{array}$ \\
Enterococcus spp. & Ampicillin $(10 \mu \mathrm{g})$ & $1 \%$ Sodium hypochlorite \\
S. aureus & Erythromycin $(15 \mu \mathrm{g})$ & $1 \%$ Ethyl alcohol Sodium hypochlorite \\
Coagulase-negative Staphylococcus & Erythromycin $(15 \mu \mathrm{g})$ & $1 \%$ Sodium hypochlorite \\
\hline
\end{tabular}

Aspergillus spp., a metabolite called mycotoxin is responsible for causing damage to human and animal health. Mycotoxicosis is the name of the disease of interest in public health, and the signs are according to the dosage, species, age, and animal health (MELO et al., 2009; MENEZES et al., 2017).

Epicoccum spp. have already been isolated from the external auditory canal of healthy cats (CARDOSO et al., 2013). Epicoccum spp. and Drechslera spp. have not been studied in veterinary medicine and are generally related to plant disorders (CARVALHO et al., 2017).

Some of the fungi found are environmental. Some improvements can be applied to assist in hospital disinfection, such as using hydrogen peroxide by means of aerosols, reducing the fungal load. This technique can be used as a disinfection step integrated with periodic cleaning procedures (DIAS, 2018).

Disinfectants are microbicidal products that destroy the microorganism's cell wall or interfere with its metabolism. In disinfection, there is a reduction in the microorganism load; in contrast, sterilization kills all microorganisms present (AMARAL et al., 1998; BOTELHO et al., 2008).

For disinfection of surfaces, such as service tables, ethyl alcohol is used, which has good germicidal activity and low cost. Ethyl alcohol has a broad and fast spectrum of action against vegetative bacteria, viruses, and fungi but cannot destroy spores (MAZZOLA et al., 2003). Ethyl alcohol was efficient in the analyzed surfaces because bacterial growth in the swab technique was within the parameters described by the APHA.

Similar to this study, benzalkonium chloride and sodium hypochlorite were effective against bacteria analyzed in a previous study (MASOTTI et al., 2019). Benzalkonium chloride was also an effective disinfectant against 10 Escherichia coli strains (MENEZES et al., 2017). Tests have proven the bactericidal effect in open packs of $70 \%$ ethyl alcohol and 1\% sodium hypochlorite even after 21 days (ANVISA, 2007).

In contrast, Enterococcus strains were resistant to alcoholic solutions with 23\% isopropyl alcohol (MORIYA \& MÓDENA, 2008). When 70\% ethyl alcohol is applied on hands and surfaces, a good part of the product can be lost, not achieving the desired effect.

The disinfectants evaluated showed antimicrobial activity against the tested microorganisms, promoting significant growth inhibition halos. However, the resistance presented by the four microorganisms against $1 \%$ sodium hypochlorite and the resistance of Rothia spp. and Enterococcus spp. to $70 \%$ ethyl alcohol represent a potential risk. Therefore, the hygiene procedure should be reviewed.

Sodium hypochlorite is used in the hospital at $1 \%$ concentration, as it is recommended for disinfecting fixed surfaces (floors and walls). This product has the disadvantage of being unstable, being affected by sunlight, temperatures above $25^{\circ} \mathrm{C}$, acidic $\mathrm{pH}$, and inactivated in the presence of organic matter (SOUZA \& DANIEL, 2005; PEREIRA et al., 2015).

This study was limited and focused on sample collection after sanitation. This could have been done before the procedures, which would have allowed assessing whether there was a decrease in the microbiota after sanitation. A sensitivity test to antifungals could also be performed to learn about the possible resistance presented by microorganisms.

After the analysis of this research, changes in hospital hygiene processes are expected.

\section{CONCLUSION}

This study made it possible to verify the presence of microorganisms in different sectors of the university veterinary hospital rooms after sanitation, 
identifying outpatient clinics as the most contaminated places. This was expected to occur because the flow of patients and people was greater (more daily visits), only the use of laboratory coats was required, and day clothing and footwear were permitted. These points contributed to a different and larger microbial load. Thus, the frequency of cleaning could be higher, or the concentration of the product should be modified.

In other places, such as the surgical technique center, hygiene procedures were satisfactory, as it was a controlled room, where the number of visitors is limited and the use of specific and restricted clothing is mandatory, such as surgical scrubs, masks, and sanitized shoes.

The microorganisms found are possible etiological agents of hospital infections. The bacterial colonies were identified as Rothia spp., coagulase-negative Staphylococcus spp., S. aureus, and Enterococcus spp. For fungal identification, some were classified as zygomycetes, and the others were Cladosporium spp., Epicoccum spp., Drechslera spp., Scopulariopsis spp., and Penicillium spp. The application of sanitation protocols for different places and surfaces in addition to the guidance of students and tutors regarding hygienic hands and continuing education of professionals can reduce the contamination.

With the results of the antibiogram and the sensitivity test to disinfectants, there was a worrying resistance to some tested active principles, demonstrating that hygiene procedures should be reviewed. Rothia spp. and $S$. aureus were resistant to $15 \mu \mathrm{g}$ erythromycin, coagulase-negative Staphylococcus spp. were resistant to $15 \mu \mathrm{g}$ erythromycin and $25 \mu \mathrm{g}$ sulfazotrim, and Enterococcus spp. were resistant to $10 \mu \mathrm{g}$ ampicillin. In the disinfectant efficiency test, all bacteria found in the study showed resistance to $1 \%$ sodium hypochlorite solution. Rothia spp. and Enterococcus spp. showed resistance to $70 \%$ ethyl alcohol.

Still, with regard to bacterial resistance, it is necessary for the hospital's routine to implement the performance of the antibiogram that helps in the rational use of antimicrobials, as the changes that lead to resistance are accelerated by the incorrect use of drugs.

Finally, these data are relevant for knowledge of the hospital microbiota at the intersection of possible cases of hospital infections.

\section{DECLARATION OF CONFLICT OF INTEREST}

The authors declare no conflict of interest. The founding sponsors had no role in the design of the study; in the collection, analyses, or interpretation of data; in the writing of the manuscript, and in the decision to publish the results.

\section{AUTHORS' CONTRIBUTIONS}

All authors contributed equally to the conception and writing of the manuscript. All authors critically revised the manuscript and approved the final version.

\section{REFERENCES}

AMARAL, R. C. et al. Normal microflora of the ear canal in healthy cats. Cienc. Rural, Santa Maria, v.28, n.3, p.441-445, Sept. 1998. Available from: $<\mathrm{http} / /$ www.scielo.br/scielo.php?script=sci arttext\&pid=S0103-84781998000300015\&lng=en\&nrm=iso $>$. Accessed: Mar. 16, 2021. doi: 10.1590/S0103-84781998000300015.

ANDERSEN B. $\mathrm{M}$ et al. Floor cleaning: effect on bacteria and organic materials in hospital rooms. Journal of Hospital Infection. 2009. 71, 57-65. Available from: <https://www. journalofhospitalinfection.com/article/S0195-6701(08)00389-7/ pdf>. Accessed: May, 18, 2021. doi: 10.1016/j.jhin.2008.09.014.

ANDRADE, D; et al. Microbiological condition of hospital beds before and after terminal cleaning. Rev. Saúde Pública, São Paulo, v.34, n.2, p.163-169, Apr. 2000. Available from: $<$ http://www.scielo.br/scielo.php?script=sci_arttext\&pid=S003489102000000200010\&lng=en\&nrm=iso $>$. Accessed: May, 18, 2021. doi: 10.1590/S0034-89102000000200010.

ANVISA. Agência nacional de vigilância sanitária. Detecção e identificação de bactérias de importância médica, 2004. Available from: <https://www.anvisa.gov.br/servicosaude/ microbiologia/mod_5_2004.pdf $>$. Accessed: May, 18, 2021.

ANVISA. Agência nacional de vigilância sanitária. Resolução da Diretoria Colegiada- RDC $\mathbf{n}^{\mathbf{0}} \mathbf{3 5}$, de 16 de agosto de 2010. Available from: <http://bvsms.saude.gov.br/bvs/saudelegis/ anvisa/2010/res0035_16_08_2010.html>. Accessed: May, 18, 2021.

ANVISA. Agência nacional de vigilância sanitária. Resolução da diretoria colegiada- RDC $\mathbf{n}^{\mathbf{0}} \mathbf{1 4}$, de 28 de fevereiro de 2007. Available from: <https://www.cevs.rs.gov.br/upload/ arquivos/201611/08140937-rdc-14-2007.pdf $>$. Accessed: May, 18, 2021.

ARAÚJO P. L.; et al. Prevalence of health assistance infection in patients hospitalized in intensive therapy unit. Enfermería Global. 2018;17(4):278-315. Available from: <https://scielo.isciii.es/pdf/ eg/v17n52/pt_1695-6141-eg-17-52-278.pdf>. Accessed: Mar. 01, 2021. doi: 10.6018/Eglobal.17.4.289311

ASCHER, D. P.; et al. Infections due to Stomatococcus mucilaginosus: 10 cases and review. Reviews of Infectious Diseases, v.13, n.6, p.1048-1052, 1991. Available from: <https:// pubmed.ncbi.nlm.nih.gov/1775836/>. Accessed: Mar. 01, 2021. doi: 10.1093/clinids/13.6.1048

BANDEIRA N. C.; et al. Ação de antissépticos e desinfetantes de uso doméstico sobre Enterococcus spp. isolados do arroio Dilúvio, RS, Brasil. R. Bbras. Bioci., Porto Alegre, v. 17, n.2, p. 77-86, jul./dez. 2019. Available from: <http://www.ufrgs.br/ seerbio/ojs/index.php/rbb/article/view/4219/1402>. Accessed: Mar. 03, 2021.

BARTLETT, J. G.; et al. Seven ways to preserve the miracle of antibiotics. Clinical Infectious Diseases, v.56, n.10, p.1445-1450, 2013. Available from: $<$ https://pubmed.ncbi.nlm.nih.gov/23403172/>. Accessed: Mar. 01, 2021. doi: 10.1093/cid/cit070. 
BOTELHO, L. S.; et al. Fungi associated to the seeds of ipêamarelo (Tabebuia serratifolia) and ipê-roxo (Tabebuia impetiginosa): incidence, germination effect and seedlings transmission. Summa Phytopathol., Botucatu, v.34, n.4, p.343348, Dec. 2008. Available from: <http://www.scielo.br/scielo. php?script $=$ sci_arttext\&pid=S0100-54052008000400008\&ln $\mathrm{g}=$ en\&nrm=iso $>$. Accessed: Mar. 03, 2021. doi: 10.1590/S010054052008000400008 .

BRASIL. Ministério da Saúde. Gabinete do Ministro. Portaria $\mathbf{n}^{\mathbf{0}}$ 2616, de 12 de Maio de 1998

CAMPOS, A.C.F.B.; et al. Antimicrobial Resistance of Enterococcus faecalis and Enterococcus faecium isolated from poultry carcasses. Pesq. Vet. Bras., Rio de Janeiro, v.33, n.5, p.575-580, May, 2013. Available from: <http://www.scielo.br/ scielo.php?script $=$ sci_arttext\&pid $=\mathrm{S} 0100-736 \mathrm{X} 2013000500004 \&$ lng $=$ en\&nrm $=$ iso $>$. Accessed: Dec. 15,2020 . doi: $10.1590 / \mathrm{S} 0100$ 736X2013000500004.

CARACIOLO, F. B.; et al. Antimicrobial resistance profile of Staphylococcus aureus isolates obtained from skin and soft tissue infections of outpatients from a university hospital in Recife -PE, Brazil. An. Bras. Dermatol., Rio de Janeiro, v.87, n.6, p.857861, Dec. 2012. Available from: <http://www.scielo.br/scielo. php?script $=$ sci arttext\&pid $=$ S0365-05962012000600006\&lng $=$ en\&nrm=iso $>$. Accessed: Dec. 17, 2020. doi: 10.1590/S036505962012000600006.

CARDOSO FILHO, F. C.; et al. Monitoring of toxigenic fungi and aflatoxins in rations used in aquaculture. Ciênc. Anim. Bras., Goiânia, v.14, n.3, p.305-311, Sept. 2013. Available from: $<\mathrm{http}: / /$ www.scielo.br/scielo.php? script=sci arttext\&pid=S180968912013000300005\&lng=en\&nrm=iso $>$. Accessed: Dec. 17, 2020. doi: $10.5216 /$ cab.v14i3.15414.

CARVALHO, D.; et al. Atividade dos desinfetantes cloreto de benzalcônio e iodóforo sobre cepas de Escherichia coli patogênica aviária isoladas em frangos de corte. Rev. Bras. Saúde prod. anim., Salvador, v.18, n.1, p.10-15, Mar. 2017. Available from: $<$ http://www.scielo.br/scielo.php?script=sci arttext\&pid=S151999402017000100010\&lng=en\&nrm=iso $>$. Accessed: Dec. 17, 2020. doi: $10.1590 / \mathrm{s} 1519-99402017000100002$.

CDC - Centers for Disease Control and Prevention. Office of Infectious Disease Antibiotic resistance threats in the United States. 2017.

DIAS, A. S. Micotoxinas em produtos de origem animal. Revista Científica de Medicina Veterinária, n.30, 2018. Available from: $<$ https://pesquisa.bvsalud.org/portal/resource/pt/vti-738109>. Accessed: Dec. 17, 2020

DRESCH, F. et al. Contaminação de superfícies localizadas em unidades de terapia intensiva e salas de cirurgia: uma revisão sistemática da literatura. Revista de Epidemiologia e Controle de Infecção, Santa Cruz do Sul, v.8, n.1, jan. 2018. Available from: <https://online.unisc.br/seer/index.php/epidemiologia/ article/view/9897>. Accessed: Dec. 17, 2020. doi: 10.17058/reci. v1i1.9897.

FANOURGIAKIS, P. et al. Bacteremia due to Stomatococcus mucilaginosus in neutropenic patients in the setting of a cancer institute. Clinical Microbiology and Infection, v.9, n.10, p.1068 1072, 2003. Available from: <https://pubmed.ncbi.nlm.nih. gov/14616756/>. Accessed: Dec. 17, 2020.
FERREIRA, A. M.; et al. Avaliação da desinfecção de superfícies hospitalares por diferentes métodos de monitoramento. Rev. Latino-Am. Enfermagem, Ribeirão Preto, v.23, n.3, p.466-474, jun. 2015. Available from: <https://www.scielo.br/pdf/rlae/v23n3/ pt_0104-1169-rlae-23-03-00466.pdf > . Accessed: Dec. 17, 2020 doi: $10.1590 / 0104-1169.0094 .2577$

HORNER, R. et al. Antimicrobial susceptibility among isolates of Enterococcus from Hospital Universitário de Santa Maria. Jornal Brasileiro de Patologia e Medicina Laboratorial. 2005, v.41, n.6 [Acessado 2 Agosto 2021], pp. 391-395. Available from: $<$ https https://www.scielo.br/j/jbpml/a/9cZpGr6kZ6f8KdfT7jtG vCf/?lang $=\mathrm{pt}>$. Accessed: Aug. 02, 2021. doi: 10.1590/S167624442005000600004

ISHII, J. B.; et al. Resistance of bacteria isolated from dogs and cats at Veterinary Hospital of Universidade Estadual de Londrina (2008-2009). Pesq. Vet. Bras., Rio de Janeiro, v.31, n.6, p.533537, June 2011. Available from: <http://www.scielo.br/scielo. php?script $=$ sci_arttext\&pid $=$ S0100-736X2011000600013\&lng $=$ en\&nrm=iso $>$. Accessed: Jan. 10, 2021. doi: 10.1590/S0100736X2011000600013

JARRAH, S.A.; et al. Cladosporium cladosporioides isolated from a cat with squamous cell carcinoma. Arq. Bras. Med. Vet. Zootec., Belo Horizonte, v.69, n.2, p.377-380, Apr. 2017. Available from: $<$ http://www.scielo.br/scielo.php?script=sci_arttext\&pid=S010209352017000200377\&lng=en\&nrm=iso>. Accessed: Jan. 10, 2021. doi: $10.1590 / 1678-4162-9139$.

KOBAYASHI, C. C. B. A.; et al. Associated antimicrobial resistance in Enterococcus spp. clinical isolates. Rev. Soc. Bras. Med. Trop., Uberaba, v.44, n.3, p.344-348, June 2011. Available from: $<$ http://www.scielo.br/scielo.php?script=sci_arttext\&pid=S0037$86822011000300017 \& \operatorname{lng}=$ en\&nrm=iso $>$. Accessed: Feb. 10, 2021. doi: $10.1590 / \mathrm{S} 0037-86822011005000033$.

LIMA, F. L. O.; et al. Enterococcus spp. resistant to vancomycin and its spread in infections in the hospital environment. Research, Society and Development, [S. l.], v.9, n.8, p.e738986404, 2020. Available from: $<$ https://rsdjournal.org/index.php/rsd/article/ view/6404>. Accessed: Aug. 2, 2021. doi: 10.33448/rsd-v9i8.6404.

MASOTTI, F.; et al. Effectiveness of air disinfection by ozonation or hydrogen peroxide aerosolization in dairy environments. Food Control, v.97, p.32-38, 2019. Available from: <https://www. sciencedirect.com/science/article/pii/S0956713518305231>. Accessed: Feb. 10, 2021.

MAZZOLA, P. G.; et al. Determination of decimal reduction time (D-value) of chemical agents used in hospital disinfection. Braz. J. Microbiol., São Paulo, v.34, supl.1, p.33-34, Nov. 2003. Available from: <http://www.scielo.br/scielo.php?script=sci arttext\&pid $=$ S 1517-83822003000500011\&lng $=$ en\&nrm $=$ iso $>$. Accessed:Feb. 24,2021. doi: 10.1590/S1517-83822003000500011.

MELO, L. L. S.; et al. Environmental fungal flora in Pediatric and Neonatal Intensive Care Units at a tertiary hospital. Rev. Paul. Pediatr., São Paulo, v.27,n.3, p.303-308, Sept. 2009. Available from: $<$ http://www.scielo.br/scielo.php?script=sci_arttext\&pid=S010305822009000300011\&lng=en\&nrm=iso $>$. Accessed: Nov. 09, 2020. doi: $10.1590 / \mathrm{S} 0103-05822009000300011$

MENEZES, C. P.; et al. Cladosporium spp: Morphology, infections and pathogenic species. Acta Brasiliensis, v.1, n.1, p.23-27, 2017. Available from: <http://revistas.ufcg.edu.br/ActaBra/index.php/ 
actabra/article/download/6/3/>. Accessed: Nov. 09, 2020. doi: 10.22571/Actabra1120176.

MORAES, G. M.; et al. Infecção ou colonização por microorganismos resistentes: identificação de preditores. Acta Paul. Enferm., São Paulo, v.26, n.2, p.185-191, 2013. Available from: $<$ http://www.scielo.br/scielo.php?script=sci_arttext\&pid=S010321002013000200013\&lng=en\&nrm=iso $>$. Accessed: May, 13, 2021. doi: 10.1590/S0103-21002013000200013.

MORIYA, T.; MÓDENA, J. L. P. Assepsia e antissepsia: técnicas de esterilização. Medicina (Ribeirão Preto), [S. l.], v.41, n.3, p.265-273, 2008. Available from: <https://www.revistas.usp.br/ rmrp/article/view/272>. Accessed: Oct. 13, 2021. doi: 10.11606/ issn.2176-7262.v41i3p265-273.

MUNDIM, G. J.; et al. Evaluation of presence of Staphylococcus aureus on the beds of Hospital Escola's Intensive Care Unit, concerning the position on the mattress, before and after cleaning. Rev. Soc. Bras. Med. Trop., Uberaba, v.36, n.6, p.685688, Dec. 2003. Available from: <http://www.scielo.br/scielo. php? script $=$ sci_arttext $\&$ pid $=$ S0037-86822003000600007\&ln $\mathrm{g}=$ en\&nrm $=$ iso $>$. Accessed: Sep. 10, 2020. doi: 10.1590/S003786822003000600007 .

NEELY, A. N.; MALEY, M. P. Survival of enterococci and staphylococci on hospital fabrics and plastic. Journal of clinical microbiology, v.38, n.2, p.724-726, 2000. Available from: <https:// jcm.asm.org/content/38/2/724.short>. Accessed: Jan. 13, 2021. doi: 10.1128/JCM.38.2.724-726.2000

NEGREIROS, M. O.; et al. In vitro antimicrobial activity of essential oils from Heterothalamus Less. (Asteraceae) against clinically relevant bacterial and fungal species. R. Bras. Bioci., Porto Alegre, v.14, n.1, p.26-31, jan./mar. 2016. Available from: <http://www. ufrgs.br/seerbio/ojs/index.php/rbb/article/view/3403>. Accessed: Jan. 13, 2021

PEREIRA, S. S. P. et al. Disinfection with sodium hypochlorite in hospital environmental surfaces in the reduction of contamination and infection prevention: a systematic review. Rev Esc Enferm USP, 2015; 49(4):681-688. Available from: <https://www.scielo. $\mathrm{br} / \mathrm{j} /$ reeusp/a/3zd5wCqFcXr4sTPDXd56Lsm/?lang=pt\&format $=\mathrm{p}$ df>. Accessed: Aug. 2, 2021.

SANTOS, H. G.; et al. Multirresistência bacteriana: a vivência de pacientes internados em hospital-escola do município de Londrina, Paraná. Ciência, Cuidado e Saúde, v.9, n.1, p.74-80, 2010. Available from: <https://periodicos.uem.br/ojs/index.php/ CiencCuidSaude/article/view/7178/5827>. Accessed: Jan. 13, 2021. doi: 10.4025/cienccuidsaude.v9i1.7178.
SANTOS, N. Q. Bacterial resistence in the context of hospital infection. Texto contexto - enferm., Florianópolis, v.13, n.spe, p.64-70, 2004. Available from: <https://www.scielo.br/pdf/tce/ v13nspe/v13nspea07.pdf $>$. Accessed: Jan. 13, 2021.

SCHROPFER, D. L.; et al, 2017. Ocorrência de fungos dermatófitos em cães do oeste catarinense. $2^{\circ}$ simpósio e mostra científica de pequenos animais. $\mathrm{FAI}$

SFACIOTTE R. A. P.; et al. Determinação dos pontos críticos de contaminação e avaliação de protocolos de desinfecção hospitalar na área veterinária. Revista de Ciência Veterinária e Saúde Pública. v.1 n.1 2014. Available from: <https://periodicos.uem.br/ ojs/index.php/RevCiVet/article/view/23280>. Accessed: Jun. 05, 2021. doi: 10.4025/revcivet.v1i1.23280.

SILVA, A. P.; et al. Antimicrobial susceptibility of Staphylococcus spp. isolated from canine superficial pyoderma. Pesq. Vet. Bras., Rio de Janeiro, v.34, n.4, p.355-361, Apr. 2014. Available from: $<$ http:/www.scielo.br/scielo.php?script $=$ sci arttext\&pid=S0100736X2014000400010\&lng=en\&nrm=iso>. Accessed: Jan. 13, 2021. doi:10.1590/S0100-736X2014000400010.

SILVA, L; et al. Evaluation of environmental contamination at veterinary teaching hospital and cumulative antibiogram. Revista Veterinária em Foco, v.14, n.2, 2017. Available from: $<$ http://www.periodicos.ulbra.br/index.php/veterinaria/article/ view/3707/2840>. Accessed: Jan. 13, 2021

SOUZA, J. B. e DANIEL, L. A. Comparison between sodium hipoclorite and peracetic acid for $E$. coli, coliphages and $C$. perfringens inactivation of high organic matter concentration water. Engenharia Sanitaria e Ambiental. 2005, v.10, n.2 Available from: < https://www.scielo.br/j/esa/a/VtMCwWX7kDhr GrSzDYs6xTj/?lang=pt $>$. Accessed: Jan. 13, 2021. doi: 10.1590/ S1413-41522005000200004

SOUZA, R. M. DE et al. Análise microbiológica de copos de liquidificador e placas de corte em cantinas de escolas públicas do GuaráDF. Higiene Alimentar, Curitiba, v.30, n.260/261, p.143-148, 2016. Available from: $<$ https://docs.bvsalud.org/biblioref/2016/12/827205/260261-sitecompressed-143-148.pdf>. Accessed: Aug. 2, 2021.

TORRES, A. S.; et al. Isolation and identification of Staphylococcus aureus health professionals nasopharynx from: a literature review. Temas em Saúde. Vol.17, n.2, João Pessoa, 2017. Available from: $<$ https://temasemsaude.com/wp-content/uploads/2017/08/17211. pdf>. Accessed: Mar. 01, 2021.

TORTORA, G. J.; et al. Microbiologia. 10. ed., Porto Alegre: Artmed, 2010. 